\title{
PREFERENSI KONSUMEN TERHADAP DAGING DOMBA DI JAWA BARAT
}

\author{
Dadi Suryadi, Sri Rahayu, Cecep Firmansyah,dan Sondi Kuswaryan \\ Fakultas Peternakan Universitas Padjadjaran \\ E-mail : dsryd_46@yahoo.co.id
}

\begin{abstract}
ABSTRAK. Penelitian ini bertujuan untuk mengetahui preferensi konsumen terhadap daging domba. Metode yang digunakan dalam penelitian ini adalah survey. Lokasi penelitian di wilayah jalur wisata Bogor-Cianjur, dan Kota Bandung yang ditentukan secara purposive. Sampel yang digunakan sebanyak 109 responden, dengan model analisisUji Chochran Q Test, dan Multi Atribut Fishbein. Hasil penelitian menunjukan bahwa : (a) Terdapat empat dari 18 atribut daging domba yang valid disepakati konsumen daging domba yaitu: keempukan daging, harga daging, bagian potongan karkas, dan aroma, (b) konsumen lebih menyukai: daging domba empuk yang ditandai konsistensi kenyal jika ditekan dengan jari; harga daging yang layak sesuai dengan kualitas; bagian potongan karkas paha belakang dan depan; daging memiliki aroma khas dan tidak berbau busuk, (c) prioritas atribut yang dipertimbangkan dalam membeli daging domba dari tingkatan penting sampai sangat penting, yaitu : keempukan daging, harga daging, bagian potongan karkas, dan aroma daging, (d) Sikap konsumen daging domba sebagian besar ada pada kategori positif sampai sangat positif, dan sebagian kecil responden bersikap netral, tetapi responden tetap melakukan pembelian daging domba.
\end{abstract}

Kata Kunci : preferensi, daging domba, atribut daging domba

\section{CONSUMER PREFERENCES OF MEAT LAMB IN WEST JAVA}

\begin{abstract}
This research aims to determine consumer preferences for lamb meat. The research used the survey method. Location of research in the area of Bogor-Cianjur tourist lane, and Bandung are determined by purposive. The number of samples around 104 respondents, and analysis model used Chochran Q Test, and Multy Attributes Fishbein.The results showed that: (a) There are nine valid attributes according to consumer consideration. Simultaneously, consumers prefer 3 attributes namely lamb meat is clean, bright meat color and meat prices feasible,(b) Partially, respondents wich profession street hawkers prefers lamb meat clean, bright meat color and meat prices feasible, and respondents with professional restaurant business prefers lamb meat clean, soft meat texture, bright meat color, as well as(c) Respondents which a special sate restaurant business prefers the meat clean, bright meat color, and distinctive flavorful meat.
\end{abstract}

Key Words: preferences, lamb meat, lamb meat atribute

\section{PENDAHULUAN}

Budidaya domba di Jawa Barat merupakan sebuah budaya dan menjadi bagian dari kehidupan sebagian besar masyarakat terutama di wilayah pedesaan, sehingga populasi domba Jawa Barat menjadi yang terbesar di Indonesia. Populasi domba di Jawa Barat Tahun 2013 mencapai 9,2 juta ekor lebih, dan memberikan kontribusi terhadap populasi nasional 63,28\%. Populasi domba selama 5 tahun (2009-2013) tumbuh 12,12\% melebihi pertumbuhan populasi domba di Indonesia yang hanya 9,41 \% (diolah dari Statistik Peternakan dan Kesehatan Hewan, Tahun 2013). Sejalan dengan itu, menurut Suryadi, D., dkk., (2014) volume domba yang diperdagangkan pun cukup besar mencapai 609.301 ekor pada tahun 2013 yang terdiri dari domba potong (siap potong dan bakalan) sekitar 75,41\%, dan 24,59\% domba bibit. Daging domba yang dipasarkan pun cukup besar, hasil estimasi Suryadi, D., dkk., (2014) berkisar antara 3,49 ribu ton sampai 5,06 ribu ton Volume pasar daging domba tersebut berasal dari jumlah pemotongan domba di RPH dan Luar RPH. Statistik Peternaka Jawa Barat Tahun 2013 mencatat jumlah pemotongan domba mencapai 554.326 ekor yang terdiri dari $83,85 \%$ domba jantan dan 16,15\% domba betina. Pemotongan domba tersebut sebagian besar (90,21 \%) dilakukan di luar RPH. Besarnya volume perdagangan domba dan daging domba di Jawa Barat belum sepenuhnya direspon oleh masyarakat produsen domba. Pola usaha belum beranjak dari motif usaha yang masih bersifat sampingan, skala usaha rendah, dan memanfaatkan sumberdaya lokal, semi subsisten. Walaupun demikian performa usahaternak domba masih bermakna dalam menjaga financial security terutama bagi masyarakat miskin di pedesaan. Respon masyarakat yang beternak domba terhadap perkembangan pasar sangat penting sehubunganterjadi dinamika dan pergeseran preferensi konsumen terhadap daging domba itu sendiri. Perubahan preferensi konsumen daging domba oleh masyarakat produsen belum direpon dalam bentuk perbaikan pola budidaya dan dinilai masih kurang inovasi untuk menghasilkan domba dan daging domba yang memenuhi harapan konsumen.

Harapan konsumen yang tergambar dalam preferensi perlu digali dan diketahui, sebagai bahan perbaikan pada subsistem produksi untuk menghasilkan domba dan daging domba yang marketable, dan diharapkan perbaikan pola budidaya tersebut lebih meningkatkan fungsi domba sebagai pengaman keuangan rumah tangga peternak dan mampu meningkatkan perekonomian pedesaan. 
Potensi pasar daging domba yang terus berkembang, dan arah permintaan produk saat ini mulai berkembang kearah produk yang relevan dengan kebutuhan konsumen, secara lebih spesifik, maka peternak domba di Jawa Barat harus menyesuaikan produknya dengan kebutuhan konsumennya. Tantangan terhadap domba Jawa Barat datang dari provins lain, dan akan semakin berat pada tahun 2015 sejalan dengan berlakuny perdagangan bebas Asean (AFTA).

Upaya untuk meningkatkan daya saing dan mendapat sambutan pasar, selayaknya domba diproduksi sesuai dengan keinginan dan kebutuhan konsumen. Terdapat atribut yang dipertimbangkan dalam pembelian daging domba menjadi bagian penting untuk diketahui, dan menjadi faktor pengarah bagi penentuan kualitas daging domba yang diinginkan konsumen (perceived quality). Atribut tersebut pada akhirnya akan terimplementasikan sebagai preferensi konsumen terhadap daging domba, pada masing-masing segmen pasar yang sekarang ada. Variabel yang diidentifikasi dari konsumen daging domba di pasar, harus menjadi pemandu bagi proses produksi domba, akan lebih baik lagi bila kualitas daging domba yang dihasilkan dan dipasarakan mampu melebihi harapan konsumen daging domba, untuk masing-masing segmen pasarnya. Permasalah dalam penelitian ini dirumuskan sebagai berikut :

a. Bagaimana preferensi konsumen terhadap daging domba

b. Atribut apa saja yang menjadi prioritas pertimbangan konsumen dalam melakukan pembelian daging domba

c. Bagaimana sikap konsumen terhadap kualitas daging domba yang ada di pasaran.

Penelitian ini bertujuan untuk : (a) Menganalisis preferensi konsumen terhadap daging domba, (b) menganalisis prioritas atribut daging domba yang menjadi prioritas pertimbangan dalam pembelian daging domba, dan (c) menganalisis sikap konsumen terhadap kualitas daging domba. Informasi ilmiah dari hasil penelitian ini bermanfaat bagi pengembangandomba dalam melakukan breeding, dan budidayanya. Hasil ini juga bermanfaat sebabagi acuan pengembangan domba bagi pengambil kebijakan di pemerintahan, pengusaha domba, dan para peternak dalam budidayanya dapat menghasilkan domba sesuai dengan preferensi konsumen, dan peranan domba dalam rumah tangga peternak menjadi financial security yang lebih besar, dan mampu menghidupkan perekonomian perdesaan.

\section{METODE}

Metode yang digunakan dalam penelitian ini adalah survey. Lokasi penelitian ditentukan secara purposive, yaitu di Kota Bandung, dan di wilayah jalur wisata Bogor-Cianjur, dengan pertimbangan bahwa
Kota Bandung merupakan salah satu pusat konsumsi daging domba di Jawa Barat, dan Jalur Wisata Puncak Bogor-Cianjur banyak berkembang usaha kuliner yang menjual produk olahan daging domba terutama sate. Daerah tersebut banyak dikunjungi oleh wisatawan domestik berbagai kalangan, serta wisatawan mancanegara. Lokasi penelitian di Kota Bandung ditentukan secara purposive dengan pertimbangan usaha kuliner yang memakai "nama rumah makan sate". Berdasarkan hal tersebut terpilih Kecamatan Coblong sebagai wilayah penelitian.

Responden penelitian ini adalah orang yang bergerak dalam usaha/ manajemen kuliner yang melakukan pembelian daging domba untuk bahan baku produk olahan daging domba. Jumlah responden sebanyak 109 orang yang terdiri dari responden di kawasan wisata puncak sebanyak 37 orang. Responden di Kota Bandungsebanyak 72 orang. Pengambilan responden seluruhnya ditentukan secara sensus.

Model analisis yang digunakan adalah uji validasi atribut dengan menggunakan Chochran Q Test, dan sikap konsumen terhadap daging dombamenggunaka anlisisMulti Atribut Fishbein. Formulasi Chochran $Q$ Test sebagai berikut :

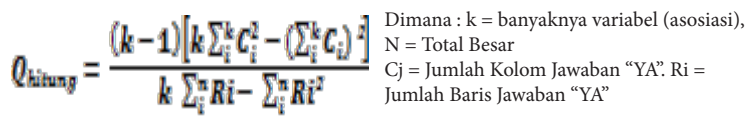

Hasil $\mathrm{Q}_{\text {hitung }}$ dibandingkan dengan $\mathrm{Q}_{\text {tabel } \alpha=0,05}$ dengan derajat bebas (k-1) pada tabel Chi Square Distribution. Kaidah pengambilan keputusannya adalah : (a) tolak Ho dan terima Ha, jika $\mathrm{Q}_{\text {hitung }} \geq \mathrm{Q}_{\text {tabel } \alpha=0,05}$, dan terima Ho dan tolak Ha, jika $\mathrm{Q}_{\text {hitung }}<\mathrm{Q}_{\text {tabel } \alpha=0,05}$. Jika tolak Ho berarti proporsi jawaban YAuntuk seluruh atribut dianggap masih berbeda, atau belum ada kesamaan pendapat diantara para responden tentang atribut-atribut tersebut sebagai bahan yang dipertimbangkan. Jika terima Ho berati proporsi jawaban YA pada semua atribut dianggap sama, artinya seluruh responden menyetujui atribut-atribut tersebut adalah yang dipertimbangkan.

$\mathbf{A}_{\mathrm{o}}=\sum_{\mathrm{i}=1}^{n}\left(b_{\mathrm{i}}\right)\left(\mathrm{e}_{\mathrm{i}}\right)$

Analisis sikap responden terhadap terhadap objeknya menggunakan formulasi:

Keterangan : $\mathbf{A}_{\mathbf{o}}=$ Sikap total individu terhadap objek, $\mathbf{b}_{\mathbf{i}}=$ : kekuatan keyakinan konsumen bahwa objek memiliki atribut ke-i, $\mathbf{e}_{\mathrm{i}}=$ evaluasi kepercayaan individu mengenai atribut ke-i n = Jumlah kriteria atribut yang relevan

\section{HASIL DAN PEMBAHASAN}

\section{Preferensi Konsumen terhadap Daging Domba}

Pengolah daging domba (PDD) selaku responden dalam konteks pemasaran daging domba tergolong kedalam konsumen daging domba. Daging domba bagi PDD merupakan salah satu bahan baku untuk memproduksi 
berbagai daging domba olahan seperti sate, tongseng, gule, untuk dijual kembali. Survey di Kota Bandung dan jalur wisata puncak Bogor-Cianjur, berhasil menghimpun 109 responden dari PDD yang terkelompok kedalam pedagang kaki lima (PKL) 55 orang, Rumah Makan (RM) 27 orang, rumah makan khusus sate (RMK) 27 orang.

Tabel 1. Karakteristik Pengolah Daging Domba Menurut Umur, Pengalaman dan Omset Usaha

\begin{tabular}{lccr}
\hline $\begin{array}{l}\text { Kategori } \\
\text { Usaha/ } \\
\begin{array}{l}\text { Variabel } \\
\text { Statistik }\end{array}\end{array}$ & $\begin{array}{c}\text { Umur } \\
\text { (tahun) }\end{array}$ & $\begin{array}{c}\text { Pengalaman } \\
\text { (tahun) }\end{array}$ & \multicolumn{1}{c}{$\begin{array}{c}\text { Omset } \\
\text { (Rp/hari) }\end{array}$} \\
\hline $\begin{array}{l}\text { A. PPD-PKL } \\
\text { (n=55) }\end{array}$ & & & \\
- Rata-rata & 31,03 & 10,39 & $556.666,67$ \\
- Min & 17,00 & 0,30 & $200.000,00$ \\
- Maks & 55,00 & 43,00 & $2.000 .000,00$ \\
B. PPD-RM & & & \\
(n=27) & & & \\
- Rata-rata & 40,65 & 15,68 & $2.705 .882,35$ \\
- Min & 19,00 & 0,80 & $500.000,00$ \\
- Maks & 61,00 & 50,00 & $7.500 .000,00$ \\
C. PPD-RMK & & & \\
(n=27) & & & \\
- Rata-rata & 34,14 & 5,98 & $1.715 .384,62$ \\
- Min & 20,00 & 0,30 & $400.000,00$ \\
- Maks & 62,00 & 30,00 & $4.000 .000,00$ \\
\hline
\end{tabular}

Keterangan: PPD-PKL = Pengolah daging domba kategori pedagang kaki lima, PPD-RM = pengolah daging domba kategori rumah makan, dan PPD-RMK = pengolah daging domba kategori rumah makan khusus sate

Umur seseorang berkaitan erat dengan perkembangan kedewasaan berfikir di dalam menyikapi berbagai persoalan hidup termasuk dalam kegiatan usaha. Umur yang lebih muda akan lebih responsive dalam menerima suatu stimulus dibandingkan dengan umur yang lebih tua selain itu semakin cukup umur tingkat pematangan dan kekuatan seseorang akan lebih baik dalam berpikir, belajar dan bekerja, sehingga pengetahuannya pun akan bertambah (Azwar, 2007). Rata-rata umur pelaku usaha yang menjadi responden dalam penelitian ini berada pada kisaran umur produktif, dan berdasarkan hasil pengolahan data tampak rata-rata umur PDD-PKL lebih muda dari pelaku usaha PDDRM dan lebih muda dari pelaku PDD-RMK.

Peristiwa atau kejadian yang dialami seseorang dalam hidupnya akan membentuk pengetahuan, bahkan keterampilan bagi orang yang mengalami peristiwa tersebut, atau peristiwa yang dialami oleh orang lain. Seseorang yang berkecimpung dalam dunia usaha pengolahan daging domba, tentunya pengetahuan dan keterampilan tentang bagaimana cara mengolah dan bahan baku yang bagaimana pun akan dikuasai. Menurut Notoadmodjo (2010), pengalaman yang cukup lama akan menunjang keterampilan, karena pengalaman merupakan sumber pengetahuan, dan alat ukur pengetahuan. Pengalaman para responden pelaku usaha daging domba olahan untuk kategori usaha PKL rata-rata 10,39 tahun, lebih kecil dari pada rata-rata pengalaman pelaku usaha RM dan lebih besar dari pelaku RMK. Pelaku usaha tersebut juga ada yang baru melakukan usaha kurang dari satu tahun, namun hasil observasi menujukan bahwa mereka yang belum berpengalaman usaha, ternyata mereka telah bekerja pada PDD lain sebelum membuka usaha sendiri.

PPD untuk masing masing kategori memiliki omset harian, omset PPD-PKL rata-rata Rp. 556.666,67/ hari lebih kecil dari omset PPD-RM, dan omset PPDRM lebih tinggi dari omset PPD-RMK. Tingginya ratarata omset harian PPD-RM disebabkan variasi menu daging domba olahan, dan terdapat menu diluar daging domba, sehingga konsumen memilki alternatif menu lebih banyak, dan akumulasi nilai pembelian tersebut menjadi omset usaha.

\section{Atribut Kualitas Domba dan Daging Domba}

Jumlah pertanyaan tertutup yang diajukan ke pada responden sebanyak 18 atribut. Jumlah opsi jawaban sebanyak dua, yaitu : YA yang berarti atribut tersebut menjadi pertimbangan dalam membeli daging domba, dan TIDAK yang berarti tidak menjadi pertimbangan dalam pembelian domba. Data rekapitulasi jawaban menunjukan bahwa terdapat jawaban YA paling besar yaitu untuk atribut perkiraan keempukan, harga daging, dan aroma daging domba dengan proporsi jawaban masing-masing diatas 85 $\%$ dari total responden 109 orang. Proporsi jawaban TIDAK yang terbesar adalah untuk atribut berat hidup domba sebesar 86,24\% dari total responden (Tabel 2).

Tabel 2. Proporsi Jawaban Responden terhadap Atribut Daging Domba

\begin{tabular}{|c|c|c|c|}
\hline \multirow{2}{*}{ ID_Atribut } & \multirow{2}{*}{ Atribut } & \multicolumn{2}{|c|}{ Proporsi Jawaban (\%) } \\
\hline & & YA & TIDAK \\
\hline P-01 & Umur Domba & 50,46 & 49,54 \\
\hline P-02 & Jenis kelamin & 48,62 & 51,38 \\
\hline P-03 & Penanganan karkas & 32,11 & 67,89 \\
\hline P-04 & Berat hidup & 13,76 & 86,24 \\
\hline P-05 & Tekstur Daging Domba & 77,06 & 22,94 \\
\hline P-06 & Warna Daging Domba & 78,90 & 21,10 \\
\hline P-07 & Perkiraan keempukan & 89,91 & 10,09 \\
\hline P-08 & Perlemakan & 69,72 & 30,28 \\
\hline P-09 & Aroma Daging Domba & 85,32 & 14,68 \\
\hline P-10 & Bag pot karkas & 79,82 & 20,18 \\
\hline P-11 & $\begin{array}{l}\text { Penyimpanan Daging } \\
\text { Domba }\end{array}$ & 72,48 & 27,52 \\
\hline P-12 & Tempat pemotongan & 39,45 & 60,55 \\
\hline P-13 & $\begin{array}{l}\text { Pengemasan Daging } \\
\text { Domba }\end{array}$ & 38,53 & 61,47 \\
\hline P-14 & Bangsa domba & 40,37 & 59,63 \\
\hline P-15 & Kebersihan Daging Domba & 73,39 & 26,61 \\
\hline P-16 & Harga Daging Domba & 89,91 & 10,09 \\
\hline P-17 & Lokasi pembelian & 51,38 & 48,62 \\
\hline P-18 & Asal domba & 41,28 & 58,72 \\
\hline
\end{tabular}


Validasi atribut menggunakan uji Cochran dengan bantuan software SPSS 16.0, hasil pengujian dilakukan sebanyak 4 kali, dan pada pengujian terakhir diperoleh nilai Q hitung yang lebih kecil dari nilai Q tabel pada Chisquare Distribution Table pada $\alpha=0,05$. Hasil perhitungan menujukan bahwa $\mathbf{Q}_{\text {hitung } \alpha=0,05}=7,235$ lebih kecil dari $\mathbf{Q}$ tabel $\alpha=0,05=7,815$, dan diperoleh sebanyak 4 atribut yang valid (Tabel 3).

Tabel 3. Atribut-atribut Daging Domba yang Valid

\begin{tabular}{clcc}
\hline \multirow{2}{*}{ ID_Atribut } & \multirow{2}{*}{ Atribut yang Diuji } & \multicolumn{2}{c}{ Proporsi Jawaban (\%) } \\
\cline { 3 - 4 } & & YA & Tidak \\
\hline P-07 & Keempukan daging & 89,91 & 10,09 \\
P-09 & Aroma daging & 85,32 & 14,68 \\
P-10 & Bagian potongan karkas & 79,82 & 20,18 \\
P-16 & Harga daging & 89,91 & 10,09 \\
\hline
\end{tabular}

Keterangan $: \mathrm{n}=98$

Daging domba secara umum memiliki ciri-ciri khusus dibandingkan dengan daging lainnya. Ciri-ciri daging domba adalah serabut daging halus, warna merah muda, konsistensi cukup tinggi, banyak lemak di otot, bau sangat khas, dan lemak berwarna putih. Ciri-ciri tersebut pada dasarnya menjadi bagian atribut daging domba. Empat atribut yang valid (Tabel 3) terdiri dari :

a. keempukan daging berkaitan dengan ciri daging domba yang memilki kosistensi tinggi, yaitu apabila ditekan dengan jari tampak memilki konsistensi kenyal,

b. Aroma daging berkaitan dengan ciri daging domba yang memilki bau khas,

c. Bagian potongan karkas berkaitan dengan kebutuhan konsumen, dimana daging domba sebagai bahan baku produk olahan daging domba,

d. Harga daging domba berkaitan dengan kualitas.

\section{Preferensi Konsumen Daging Domba}

Kotler (1994) dalam Gumilar (1999) mengemukakan bahwa preferensi dapat digunakan oleh pengusaha (enterpreneur) untuk mengenali kebutuhan konsumen, agar diperoleh produk dengan orientasi pasar, didasarkan pada tingkat preferensi konsumen bagi tiap-tiap atribut produk. Hasil penelitian menunjukan bahwa konsumen menyukai daging domba yang empuk, keempukan daging menurut konsumen akan berpengaruh terhadap kualitas daging olahan, sehingga mereka sebelum membeli daging domba mengobservasi terlebih dahulu daging domba tersebut (Tabel 4).

Konsumen sebagaian besar mengecek keempukan daging domba dengan cara menekan permukaan daging dengan jari tangan, apabila daging yang ditekan cepat kembali, maka diyakini oleh sebagian besar konsumen adalah daging domba yang empuk. Menekan daging domba dengan jari sebenarnya untuk melihat konsistensi kekenyalan daging, karena daging yang sehat akan memiliki konsistensi kenyal. Tingkat keempukan daging ditentukan oleh kandungan jaringan ikat, semakin tua usia ternak maka susunan jaringan ikat semakin banyak sehingga daging yang dihasilkan semakin alot (liat). Muzarmis (1982) menjelaskan bahwa daging domba memiliki serat yang lebih halus dibandingkan dengan daging lainnya, jaringan sangat padat, berwarna merah muda, konsistensinya cukup tinggi, lemaknya terdapat di bawah kulit yaitu antara otot kulit. Soeparno (2005) menyatakan bahwa pengujian keempukan dapat dilakukan secara mekanik termasuk pengujian kompresi (indikasi kealotan jaringan ikat), daya putus (indikasi kealotan miofibrilar), adhesi (indeks kekuatan jaringan ikat) dan susut masak). Jika ditekan dengan jari daging yang sehat akan memiliki konsistensi kenyal. Keempukan daging domba oleh sebagin kecil responden dilihat dari ketebalan daging, dan mempercayai bahwa bagian-bagian karkas memilki keempukan daging yang berbeda. Menurut Soeparno (2005), menyatakan bahwa bagian potongan karkas dapat mempengaruhi keempukan daging, karena karkas bagian depan pada umumnya memiliki jaringan ikat yang lebih besar daripada otot-otot karkas bagian belakang. Kedua cara observasi di atas didasarkan pada pengalaman konsumen.

Tabel 4. Metode Observasi Konsumen dalam Menilai Keempukan Daging Domba

\begin{tabular}{|c|c|c|c|}
\hline No. & Metode Observasi & $\begin{array}{l}\text { Jumlah } \\
\text { (orang) }\end{array}$ & $\begin{array}{l}\text { Proporsi } \\
\quad(\%)\end{array}$ \\
\hline 1 & Menekan permukaan daging & 72 & 73,47 \\
\hline 2 & Melihat ketebalan daging & 15 & 15,31 \\
\hline 3 & $\begin{array}{l}\text { Mempercayai bagian karkas } \\
\text { tertentu }\end{array}$ & 11 & 11,22 \\
\hline & Jumlah & 98 & 100,00 \\
\hline
\end{tabular}

Aroma daging domba yang baik memiliki aroma khas daging domba, dan tidak berbau busuk. Aroma daging berhubungan dengan umur, menurut Soeparno (2005) daging dari domba berumur tua mempunyai bau yang lebih kuat daripada daging dari ternak berumur muda. Responden sebanyak 85,32 \% memiliki kesukaan terhadap aroma tersebut di atas, sebagian besar dari responden menyukai daging yang memilki aroma segar khas daging domba, dan sebagian kecil responden lebih menyukai daging yang tidak berbau busuk dan tidak bau "prengus" (Tabel 5). Bau prengus adalah bau daging yang disebabkan oleh feromon yang dihasilkan tubuh domba terutama tubuh domba jantan. Muzarmis (1982) mengemukakan bahwa daging domba sedikit berbau amonial (prengus).Daging yang tidak berbau "prengus" biasanya berasal dari domba yang relatif masih muda, dan juga dari domba yang berjenis kelamin betina. Menurut Bate-Smith (1948) dalam Soeparno (2005), pada umumnya keempukan daging menurun dengan meningkatnya umur ternak.

Soeparno (2005) menjelaskan bahwa potongan primal karkas domba adalah bahu (shoulder, termasuk leher), rib (rusuk) atau rack, paha depan (shank) atau 
shin dan dada (breast) yang termasuk pada karkas bagian depan (fore-saddle), dan paha (leg, termasuk sirloin), loin dan flank yang termasuk sadel belakang (hindsadlle). Konsumen ternyata lebih menyukai daging domba yang berasal dari potongan pahabelakang (73 \%) dan lebih menyukai potongan paha depan $15,7 \%$, Potongan karkas lainnya yang disukai adalah lamusir (loin) dan dada (breast), namun tingkat kesukaannya relatif lebih kecil dibandingkan dengan tingkat kesukaan pada potongan paha (Tabel 6).

Tabel 5. Preferensi Konsumen terhadap Aroma Daging Domba

\begin{tabular}{rlcc}
\hline \multirow{2}{*}{ No. } & Persepsi Konsumen & \multicolumn{2}{c}{ Jumlah Responden } \\
\cline { 3 - 4 } & & ..Orang.. & $. . \% .$. \\
\hline 1 & Aroma segar khas daging & 80 & 86,02 \\
2 & $\begin{array}{l}\text { Tidak bau busuk dan tidak } \\
\text { "prengus" }\end{array}$ & 13 & 13,98 \\
\hline & Jumlah & 93 & 100,00 \\
\hline & & \multicolumn{2}{c}{ Keterangan : $\mathrm{n}=93$}
\end{tabular}

Tabel 6. Persepsi Konsumen Terhadap Potongan Karkas Daging Domba

\begin{tabular}{clcr}
\hline \multirow{2}{*}{ No. } & Persepsi Konsumen & \multicolumn{2}{c}{ Jumlah Responden } \\
\cline { 3 - 4 } & & ...Orang.. & $. . \% .$. \\
\hline 1 & Leg (paha belakang) & 65 & 73,0 \\
2 & Leg \& Loin & 14 & 15,7 \\
3 & Loin (lamusir) & 3 & 3,4 \\
4 & Breast (dada) & 7 & 7,9 \\
\hline \multirow{2}{*}{ Jumlah } & 89 & 100,00 \\
\hline & & \multicolumn{2}{c}{ Keterangan : $\mathrm{n}=89$}
\end{tabular}

Harga merupakan bagian yang selalu dipertimbangkan dalam pembelian barang terutama untuk bahan baku, hal ini terkait dengan upaya meminimlkan biaya produksi per satuan unit output/ produk. Harga diartikan sejumlah uang yang dibutuhkan untuk mendapatkan sejumlah kombinasi dari barang (Gumilar, 1999). Para pengolah daging domba dalam praktek pembelian bahan baku (daging domba) juga memperhatikan dan mempertimbangkan harga daging domba yang akan mereka beli. Para pengolah daging domba sebagian besar lebih menyukai harga daging domba yang memilki kesesuaian antara harga dengan kualitas (Tabel 7).

\section{Tabel 7. Preferensi Konsumen terhadap Harga Daging}

\begin{tabular}{ll} 
No. & \multicolumn{1}{c}{ Persepsi Konsumen } \\
1 & Kesesuain harga dengan bobot \\
2 & Kesesuaian harga dengan kualitas \\
3 & Harga relatif Muah \\
4 & Harga relatif Cukup \\
5 & Harga relatif Mahal \\
& Jumlah
\end{tabular}

Jumlah Responden

...Orang....$\%$.

$25 \quad 25,51$

$61 \quad 62,24$

$7 \quad 7,14$

$5 \quad 5,10$

$0 \quad 0,00$

$98 \quad 100,00$

Keterangan: $\mathrm{n}=98$

\section{Nilai Kepercayaan dan Evaluasi Konsumen terhadap Atribut Daging Domba}

Sikap konsumen terhadap daging domba dibentuk oleh dua variabel yaitu keyakinan/ belief $\left(\sum \mathbf{b i}\right)$, dan evaluasi/ evaluation ( $\sum$ ei) terhadap atribut-atribut daging domba yang disepakati sebagai faktor yang dipertimbangkan (atribut yang valid menurut analisis cochran test) dalam proses pembelian daging domba. Konsep sikap sangat terkait dengan konsep kepercayaan (belief) dan perilaku (behaviour). Kepercayaan konsumen adalah pengetahuan konsumen mengenai suatu objek, atributnya, dan manfaatnya (Mowen dan Minor,1998 dalam Sumarwan 2011). Kepercayaan/ belief (b) dan evaluasi/ evaluation (e) dalam analisis fishbien memiliki penafsiran dan makna tersendiri. Belief merupakan keyakinan konsumen terhadap suatu atribut atau pendapat konsumen terhadap kinerja atribut tertentu dari daging domba. Evaluation merupakan penilaian konsumen tentang seberapa penting atribut daging doma dipertimbangkan dalam proses pembelian. Keduanya diukur dalam bentuk skala nilai.

Angka rata-rata pada Tabel 8 menggambarkan, bahwa konsumen menilai keempat atribut daging domba secara rata-rata berada pada kisaran baik sampai mendekati sangat baik, dan konsumen menganggap keempat atribut tersebut penting sampai menuju sangat penting dipertimbangkan dalam pembelian daging domba.

Tabel 8. Nilai Statistik Kepercayaan Konsumen terhadap Atribut Daging Domba

\begin{tabular}{cllcc}
\hline \multirow{2}{*}{ ID_Atribut } & \multicolumn{1}{c}{ Atribut } & \multicolumn{3}{c}{ Nilai } \\
\cline { 3 - 5 } A. Kepercayaan (b) & Rata-rata & Min & maks \\
\hline P-07 & Keempukan daging & 4,30 & 3 & 5 \\
P-09 & Aroma daging & 4,00 & 1 & 5 \\
& Bagian potongan & & 2 & 5 \\
P-10 & karkas & 3,99 & & \\
P-16 & Harga daging & 4,21 & 1 & 5 \\
B. Evaluasi (e) & & & \\
P-07 & Keempukan daging & 4,25 & 3 & 5 \\
P-09 & Aroma daging & 4,13 & 1 & 5 \\
& Bagian potongan & & & \\
P-10 & karkas & 4,17 & 1 & 5 \\
P-16 & Harga daging & 4,30 & 1 & 5 \\
\hline
\end{tabular}

Atribut produk adalah unsur-unsur produk yang dipandang penting oleh konsumen dan dijadikan dasar pengambilan keputusan pembelian (Tjiptono,1997). Para konsumen menilai atribut keempukan daging domba (P-07) secara rata-rata nilai kepercayaan (b) sebesar 4,30, dengan demikian keempukan daging di mata konsumen berada pada kisaran baik menuju sangat baik, sedangkan untuk evaluasi (e) nilainya sebesar 4,25 yang berarti atribut P-07 penting sampai sangat penting untuk konsumen dalam mempertimbangkan pembelian daging domba. Rata-rata nilai atribut keempukan 
daging menunjukan bahwa nilai kepercayaan lebih tinggi dari nilai evaluasi, ini mengindikasikan bahwa atribut keempukan daging domba belum sepenuhnya memenuhi harapan konsumen

Aroma daging domba (P-09) sebagai salah satu atribut yang valid memiliki nilai rata-rata evaluasi sebesar 4,0, mengandung arti bahwa atribut tersebut dinilai baik oleh konsumen. Atribut P-09 penting menuju sangat penting bagi konsumen dalam mempetimbangkan pembelian daging domba, hal ini ditunjukan oleh ratarata-rata nilai evaluasi sebesar 4,13. Kondisi ini menjadi justifikasi terhadap pendapat Soeparno (2005), bahwa keempukan dan tekstur daging kemungkinan besar merupakan penentu yang paling penting pada kualitas daging. Nilai kepercayaan lebih kecil dari nilai evaluasi, hal ini mengindikasikan bahwa aroma daging sebagai atribut sudah melampaui harapan para konsumen terhadap atribut tersebut.

Atribut bagian potonga karkas (P-10) merupakan atribut yang dinilai mendekati baik oleh konsumen dengan besara nilai rata-rata 3,99, sedangkan nilai evaluasinya sebesar 4,17 mengindikasikan bahwa atribut tersebut merupakan bagian penting bagi konsumen dalam mempertimbangkan keputusan membeli daging domba. Besaran nilai kepercayaan dan nilai evaluasi atribut P-10 menggambarkan bahwa bagian potongan karkas sebagai atribut daging domba sudah melampau harapan para konsumen. Harga daging domba (P-16) merupakan atribut baik menuju sangat baik menurut ratarata nilai kepercayaan konsumen sebesar 4,21, sedangkan hasil evaluasi secara rata-rata nilanya sebesar 4,30 yang berarti dalam pembelian daging domba penting menuju sangat penting sebagai atribut yang dipertimbangkan. Nilai kepercayaan dan evaluasi tersebut secara umum mengindikasikan bahwa harga daging domba sebagai atribut telah melebihi harapan konsumen.

\section{Analisis Sikap Konsumen Terhadap Daging Domba}

Sikap merupakan ekspresi dari perasaan yang mencerminkan suka atau tidak suka terhadap suatu objek, dan sikap mempelajari kecenderungan memberikan tanggapan pada suatu objek baik disenangi atau tidak disenangi secara konsisten (Sutisna, 2001). Nilai sikap konsumen $\left(\mathbf{A}_{0}\right)$ terhadap keempat atribut valid bervariasi dengan rentang 44 sampai dengan 100 dengan rata-rata 70,7. Nilai sikap tersebut tidak dapat diartikan secara tepat sehubungan pengukuran sikap ini dilakukan sescara keseluruhan (overrall) terhadap keempat atribut yang valid. Variasi nilai sikap ini mengindikasikan adanya konsumen yang tidak menyukai terhadap salah satu satu atribut, tetapi konsumen tersebut menyukai atribut yang lain, dan sebaliknya, walaupun demikian konsumen tersebut tetap melakukan pembelian daging domba.

Tabel 9. Skala Sikap dan Prioritas Atribut Secara Keseluruhan

\begin{tabular}{clcc}
\hline ID_Atribut & Atribut & Skala Sikap & Prioritas \\
\hline P-07 & Keempukan daging & 18,28 & 1 \\
P-16 & Harga daging & 18,12 & 2 \\
& Bagian potongan & & 3 \\
P-10 & karkas & 16,62 & \\
P-09 & Aroma daging & 16,51 & 4 \\
\hline
\end{tabular}

Nilai sikap masing-masing atribut menunjukan prioritas pertimbangan. Atribut keempukan daging ( $\mathrm{P} 0$ 7) memilki nilai sikap terbesar dibandingkan dengan nilai sikap atribut lainnya, namun selisihnya dengan atribut harga daging (P-16) hanya sebesar 0,16, maka dapat diartikan bahwa konsumen lebih menyukai daging domba yang empuk dengan harga yang sesuai (Tabel 9).

Pertimbangan pembelian daging domba untuk setiap jenis usaha relatif berbeda, responden pengolah daging domba dengan kategori pedagang kaki lima (PKL) lebih memperhatikan dan mempertimbangkan harga dalam keputusan pembelian daging domba. Harga yang mereka sukai adalah nilai harga yang sesuai dengan kualitas daging domba itu sendiri. Responden yang berasal dari pengusaha rumah makan, dan rumah makan khusus sate lebih mempertimbangkan atribut keempukan daging domba (P-07), keempukan daging oleh responden tersebut menjadi pertimbangan utama dalam melakukan pembelian, mereka menilai keempukan daging saat pembelian dengan memperhatikan tingkat elastisitas, ketebalan, dan kepercayaan keempukan daging terhadap potongan-potongan karkas tertentu. Skala sikap dan prioritas atribut pertimbangan pembelian daging domba dapat dilihat pada Tabel 10 .

\section{Tabel 10. Skala Sikap dan Prioritas Atribut secara Parsial Menurut Jenis Usaha}

\begin{tabular}{ccccccc} 
No & \multicolumn{2}{c}{ PKL } & \multicolumn{2}{c}{ RM } & \multicolumn{2}{c}{ RMK } \\
1 & Atribut & Nilai Sikap & Ranking & Nilai Sikap & Ranking & Nilai Sikap \\
2 & P-7 & 17,24 & 2 & 19,38 & 1 & 19,42 \\
3 & P-9 & 15,43 & 4 & 17,56 & 3 & 17,81 \\
4 & P-10 & 16,94 & 1 & 16,86 & 4 & 1 \\
& P-16 & 18,44 & 17,57 & 2 & 17,98
\end{tabular}

Keterangan $: \mathrm{PKL}=$ pedagang kaki lima, $\mathrm{RM}=$ rumah makan, $\mathrm{RMK}=$ rumah makan khusus sate P-07 = Keempukan daging, P-09 = Aroma daging, P-10 = Bagian potongan,

$\mathrm{P}-16=$ Harga daging, karkas 
Berdasarkan nilai pada Tabel 8 dan lima skala interval diperoleh rentang sikap seperti pada Tabel 11. Rentang sikap tersebut merupakan dasar dalam menilai sikap konsumen terhadap atribut daging domba, apakah sikap konsumen positif atau negatif pada proses pembelian daging domba tersebut.

Tabel 11. Kelas. Rentang dan Interpretasi Sikap Konsumen

\begin{tabular}{ccl}
\hline Kelas & \multicolumn{1}{c}{ Rentang } & Interprestasi \\
\hline 1 & $4,00 \leq \mathrm{Ao} \leq 23,2$ & Sangat Negatif \\
2 & $23,2 \leq \mathrm{Ao} \leq 42,3$ & Negatif \\
3 & $42,3 \leq \mathrm{Ao} \leq 61,6$ & Netral \\
4 & $61,6 \leq \mathrm{Ao} \leq 80,8$ & Positif \\
5 & $80,8 \leq \mathrm{Ao} \leq 100$ & Sangat Positif \\
\hline
\end{tabular}

Sikap konsumen terhadap atribut daging domba positif sampai sangat positif, yaitu sebesar 77,98 \%, sedangkan 22,02\% dari responden bersikap netral Tabel 13). Hasil penelitian Wulandari, D. (2013) sebagian besar konsumen bersikap positif sampai sangat positif terhadap atribut daging domba. Konsumen yang menilai positif sampai sangat positif dan netral, seluruhnya tetap melakukan pembelian daging domba. Keputusan pembelian didasarkan pada kebutuhan bahan baku para PDD, dan pengetahuanya terhadap atribut daging domba. Menurut Sumarwan (2011) pengetahuan konsumen mengenai atribut akan mempengaruhi pengambilan keputusan konsumen.

Tabel 12. Interpretasi (rata-rata) Nilai Sikap Terhadap Daging Domba

\begin{tabular}{llrr}
\hline No & Interpretasi & $\begin{array}{c}\text { Jumlah } \\
\text { Responden } \\
\text { (orang) }\end{array}$ & $\begin{array}{c}\text { Proporsi } \\
(\%)\end{array}$ \\
\hline 1 & Sangat Positif & 22 & 20,18 \\
2 & Positif & 63 & 57,80 \\
3 & Netral & 24 & 22,02 \\
\hline & Jumlah & 109 & 100,00 \\
\hline
\end{tabular}

\section{SIMPULAN}

Preferensi konsumen daging domba ditentukan oleh empat atribut daging domba yang valid yang disepakati konsumen daging domba yaitu: keempukan daging, harga daging, bagian potongan karkas, dan aroma daging. Konsumen lebih menyukai: daging domba empuk yang ditandai konsistensi kenyal jika diekan dengan jari; harga daging yang layak sesuai dengan kuantitas dan kualitas; bagian potongan karkas paha belakang dan depan; daging memiliki aroma khas dan tidak berbau busuk,
Prioritas atribut yang dipertimbangkan dalam membeli daging domba dari tingkatan penting sampai sangat penting, yaitu : keempukan daging, harga daging, bagian potongan karkas, dan aroma daging.

Sikap konsumen daging domba sebagian besar pada kategori positif sampai sangat positif, dan sebagian kecil responden bersikap netral, tetapi responden tetap melakukan pembelian daging domba.

\section{UCAPAN TERIMA KASIH}

Terima kasih kami ucapkan kepada Pihak DIKTI yang memberikan bantuan dana penelitian dan Ketua dan Sekretaris LPPM Unpad beserta stafnya. Pemerintah Daerah dalam hal ini adalah dinas yang membidangi peternakan di Kabupaten Indramayu, Sumedang, Kota dan Kabupaten Bandung, serta Kabupaten Cianjur. Para mahasiswa yang terlibat dalam penelitian ini, yaitu Yusmi, Anthony, Siti, Gagan, Lee Van J., M. Rizal, dan Rizky

\section{DAFTAR PUSTAKA}

Azwar, 2007. Partisipasi Manusia (Teori dan Pengukurannya. Edisi ke 2. Pustaka Pelajar. Yogyakarta. 23.

Kotler, P., 1994. Manajemen Pemasaran, Analisis, Perencanaan, Implementasi, dan Pengendalian. Penerbit Erlangga. Jakarata

Suryadi, D., Sri Rahayu, Sondi Kuswaryan, 2014. Perancangan Pemasaran Untuk Domba Pedaging Padjadjaran. Laporan Akhir. Penelitian Unggulan Perguruan Tinggi. Program Desentralisasi. Universitas Padjadjaran. Sumedang.

Soeparno, 1998. Ilmu Teknologi Daging. Gadjah Mada University.Yogyakarta.

Wulandari, D., 2013. Preferensi Penjual Sate terhadap Daging Domba. Fakultas Peternakan. Universitas Padjadjaran. Sumedang.

Mowen, J.C. dan M. Minor,1992. Perilaku Konsumen. Edisi Kelima. Erlangga. Jakarta.

Tjiptono,1997. Strategi Pemasaran. Andi. Jogyakarta.

Sutisna, 2001. Perilaku Konsumen dan Komunikasi Pemasaran. Remaja Rosdakarya. Bandung

Sumarwan, U. 2001. Perilaku Konsumen. Teori dan Penerapannya dalam Pemasaran. Ghalia Indonesia. Bogor. 